\title{
THE EFFECTS OF ROOM SERVICE TO IMPROVE PATIENTS' FOOD SATISFACTION AND FOOD ACCEPTANCE
}

\section{Pengaruh Room Service terhadap Kepuasan dan Daya Terima Makan Pasien}

\author{
Muhammad Iqbal', Susetyowati ${ }^{2}$, Martalena Br Purba ${ }^{3}$ \\ ${ }^{1}$ Clinical Nutrition Department, State Polytechnic of Jember, Jember \\ ${ }^{2}$ Health Nutrition Department, Medical Faculty, Universitas Gadjah Mada, Yogyakarta, 55281 \\ 3Nutrition Department, DR. Sardjito Hospital, Yogyakarta 55281 \\ E-mail: iqbalbasagili@gmail.com
}

\begin{abstract}
The improvement of patients' food satisfaction and acceptance in the hospitals is primarily needed in the food service system. Room service is a new concept in the food service area. This study aims to compare the effects of two different types of food service systems; room service and conventional service system. The study with quasi-experimental design is conducted to the subject of 66 inpatients who were taken using a quota sampling method. Subjects were divided into different groups, the treatment groups (room service) and control groups (conventional). Leftover food between groups was compared for 9 large meals to determine acceptability. Food satisfaction is measured on the last day with using questionnaire. The study was conducted in April-June 2014. Chi-Square test and logistic regression were used for analysis of research data. There were significant differences food satisfaction ( $R R=4.6 ; p=0.0001)$ and food acceptance ( $R R=1.94 ; p=0.0488$ ) between control and treatment group. The logistic regression test showed that room service group had higher food satisfaction and food acceptance level than control group after controlling confounding factors, which were 12,11 times $(95 \% \mathrm{Cl} 3,593-37,219)$ and 2,38 times (95\% Cl 0,68-8,31), respectively. The room service increases food satisfaction and food acceptance of patients compared with conventional systems.
\end{abstract}

Keywords: room service, food satisfaction, food acceptance, food service, plate waste

\begin{abstract}
ABSTRAK
Perbaikan sistem penyajian makanan sangat diperlukan untuk peningkatan kepuasan dan daya terima makanan pasien rumah sakit. Room service merupakan sebuah konsep baru dalam penyajian makanan. Penelitian bertujuan untuk mengetahui perbedaan kepuasan dan daya terima makan pasien pada sistem penyelenggaraan makan dengan room service dan sistem konvensional. Desain penelitian quasiexperimental dilakukan pada subjek 66 pasien rawat inap yang diambil menggunakan metode quota sampling. Subjek dibagi menjadi kelompok perlakuan (room service) dan kontrol (konvensional). Sisa makanan antar kelompok dibandingkan selama 9 kali makan besar untuk mengetahui daya terima. Kepuasan makan diukur pada hari terakhir dengan kuesioner. Penelitian berlangsung pada bulan AprilJuni 2014. Uji Chi-Square dan regresi logistik digunakan untuk analisis data penelitian. Hasil penelitian menunjukkan perbedaan yang signifikan pada tingkat kepuasan makan $(R R=4,6 ; p=0,0001)$ dan daya terima pasien ( $R R=1,94 ; p=0,0488)$ antara kelompok kontrol dan perlakuan. Hasil uji regresi logistik menunjukkan bahwa kelompok room service memiliki tingkat kepuasan 12,11 kali $(95 \% \mathrm{Cl} 3,593-37,219)$ dan daya terima 2,38 kali $(95 \% \mathrm{Cl} 0,68-8,31)$ lebih baik dibandingkan dengan kelompok kontrol setelah mengontrol variabel perancu. Metode room service meningkatkan kepuasan makan dan daya terima pasien dibandingkan dengan sistem konvensional.
\end{abstract}

Kata kunci: room service, kepuasan makan, daya terima, penyelenggaraan makanan, sisa makanan 


\section{INTRODUCTION}

$\mathrm{D}$ epartment of nutrition faces many challenges in maintaining the quality of food service to meet the nutritional needs of patients, along with food satisfaction issues and leftover food. A study in Switzerland by Stanga et al. (2003) found that the longer a patient stays in the hospital, the greater the level of dissatisfaction with the provision of food. This is exacerbated when patients stay longer in hospital have a poor condition, most likely they will lose their appetite and only slightly food eaten. ${ }^{1}$ Barton et al. (2000) found that more than 40 percent of food is wasted in the hospital. $^{2}$

The low food satisfaction and acceptance could worsen the patient's food intake and consequently difficult to heal and would extend the length of stay in hospital. ${ }^{3}$ Another source explained that malnutrition caused by low food intake in patients at the hospital can increase the cost of treatment and the risk of death. ${ }^{4}$ Prevention of malnutrition became serious concern of department of nutrition lately in order to improve the condition of patients and reduce the cost of hospital care.

While the factors that affect the amount of the patients' leftover food is not only determined by a single factor. There are a number of factors affecting among other things: tableware, food that meets the taste of patients, services provided, the cost of food, quality of food, sensory factors, food learning process, social condition, income, age, knowledge of nutrition and allergy/ intolerance the food and the type of disease. ${ }^{5-8}$

To control for factors associated with food satisfaction and acceptance of these patients needs to be a food provision system was better than the existing ones. Hospitals in some developed countries have developed a system based on the implementation of room service method.

Room service is a new system which can be applied as a substitute for the implementation of conventional system, it can also be applied in patients with certain conditions such as cancer in children. This system is a method adopted from hotel $\left.\right|^{9,10}$ or restaurant, ${ }^{11}$ which presented an interesting menu. Patients also have a better experience when they can choose their preferred menu as in a restaurant. ${ }^{12}$ This system delivers any food that patients want whenever they ask to. 9,13 Room services system is widely used by the department of nutrition in American hospitals ${ }^{14}$ and the country's traditional food delivery system is becoming obsolete. In 2011, approximately 40 percent of the 4,800 hospitals member of American Hospital Association has been using the room service system..$^{15}$

Many reasons for the food provision system in the hospital switched into the room service system. Room service method has been shown to increase satisfaction, ${ }^{11,16-18}$ improving the patient's clinical condition, ${ }^{11,17}$ improve food intake ${ }^{18}$, reducing the cost of the meal, ${ }^{18}$ accelerates the healing, ${ }^{11}$ lowering the rest of the food ${ }^{18}$ and the financial side proved able to reap the benefits more than conventional systems. ${ }^{19}$ Therefore, this study was conducted to determine the effect of the application of the system by the method of presentation of the meal room service to eat satisfaction and acceptance of the patient.

\section{METHODS}

\section{Subjects and Study Design}

The study was conducted in April 2014 until June 2014 in the patient of first and second class of wards in General Regional Hospital (RSUD) Waled, Cirebon, West Java. This study is a quasi-experimental model of post-test only design with non-equivalent group/ after-only non equivalent control group design.20,21

The minimum sample in this study, based on Lemeshow et al.'s formula ${ }^{22}$, is 66 people who meet the criteria. Criteria for inclusion of research subjects, inpatients in ward Class I and II (Nusa Indah, Orchid, and Dahlia) "Waled" Hospital aged 18-65 years old when the study started, patients were in full awareness (Compos mentis), can communicate well and had rice for the meal or soft food diet. As for the exclusion criteria are: Blind, foreign nationals, and fasting for medical treatment.

Patients who meet the criteria selected and divided into control group and the treatment group. Samples were taken using quota sampling that sample selection is performed gradually until the sample size in this study fulfilled in both groups. The dependent variable of this study is the food satisfaction and 
acceptance of patients and the independent variables are room service system.

\section{Instruments}

Data collected in this study is the patient's identity and data consisting of the disease and anthropometric data which were obtained from directly ask to the patient and from medical records. The patient's food acceptance data were obtained from converting weight of leftovers using leftovers estimation sheet and then compared to the amount of food the patient first presented. Inter-observer reliability test is done to validate the result. Data obtained from the patient satisfaction questionnaire, questions such as patient satisfaction meal that has been prepared and has been through the validity and reliability in Waled Hospital, Cirebon before the study began.

\section{Data collection}

Taking the subject of the study conducted incidentaly because patients who met the inclusion criteria came not in the same time and spread evenly in all the wards. The study subjects must first be given an explanation the purpose of the study and the advantages and disadvantages. Furthermore, subjects who are willing to follow the study asked to sign an informed consent. Subjects were also asked not to throw out the food after eating.

Leftover food in patients' plates which have been labeled, assessed by the observer. Furthermore, after 9 times eating large meal, subjects will be asked to fill in a questionnaire about food satisfaction.

\section{Statistic Analysis}

Descriptive analysis of variables using frequency distribution tables and the percentage of each group, to determine the characteristics of the subjects are presented in tabular form and narrative form. The bivariate analysis was performed to identify whether there is a relationship between two variables, namely between the dependent variable with the independent variable. Pearson chi-square, fisher exact and Kolmogorov Smirnov used for the statistic analysis. Furthermore, to determine cofounder variables or interactions, used Cochran Mantel-Haenszel test. Multivariate analysis was performed to identify whether there is any relationship between several variables, namely between the dependent variable with independent variables and external variables. The statistical test used in logistic regression.

\section{RESULTS}

Subject of the study consisted of 33 people who were divided in the control and treatment groups. No subjects in the study dropped out because quota sampling used in this study. From the results of descriptive analysis, control and treatment groups had similar characteristics in terms of gender, age, education, occupation, ethnicity and income as shown in Table 1.

Other descriptive analysis results, treatment classes, indigestion, appetite, food intake from outside the hospital and type of disease both groups say there is no difference and distributed equally. The results of the analysis are presented in Table 2.

Before analyzing the relationship between room service with patient's food satisfaction, an average total score of satisfaction of the whole subject determined first. The average score is used to categorize the satisfaction of being satisfied and not satisfied. The average score obtained from statistical calculation was 30.59 . It is said to be satisfied if the subject satisfaction scores greater than or equal to 30.59 . Instead, the subject is said to be satisfied if less satisfaction score of 30.59. Moreover, the chisquare test is done to determine differences in food satisfaction of patients using both methods are compared, room service and the conventional. After being tested, the result presented in Table 3.

From the analysis, differences in food satisfaction were found very significant between the treatment and control groups. The significant differences are evidenced by the value of $p=0.0001$ (95\% Cl 1.99 to 10.64). The result of relative risk (RR) obtained a value of 4.6. This means that the control group had the possibility to feel dissatisfied 4.6 times higher compared with treatment group with room service system.

Another bivariate test is to see the difference of patient's acceptance between the room service and conventional systems. To calculate the acceptance, the overall total for 9 subjects who ate large meals are averaged and then multiplied by 100 percent. Furthermore, the 
percentage of acceptance interpreted to be good or not good. It is said patient's food acceptance well when the average leftovers $\leq$ 25 percent. Instead, on the contrary, the acceptance is bad when the average leftovers patients $>25$ percent. After the Chi-Square test, obtained the results as presented in Table 4.

The result of the bivariate analysis is the significant difference of patient's food acceptance between the room service and conventional system. Truthfully, the number of patients that have bad food acceptance (64\%) than patients who have good food acceptance $(36 \%)$ but the results proved different significantly, as indicated by the value of $p=$ $0.0488(95 \% \mathrm{Cl} 0,89$ to 4.21$)$. The result of the calculation of the relative risk (RR) obtained a value of 1.94 . This means that the control subjects had the possibility of acceptance of the food was 1.94 times worse compared with treatment groups with room service.

Multivariate analysis result with variable patient's food acceptance obtained as much as 16 possible models and the best model is the model 6. Variable types of diseases and education are the confounding factors between room service and patient's food acceptability. OR obtained from variable room service to patient's acceptance after controlling the confounding factors was $2.38(95 \% \mathrm{Cl} 0.68$ to 8.31) therefore it can be explained that the acceptance of patients using room service system was 2.38 times greater than acceptance of patients using conventional system after controlling variable type of diseases and education.

Table 1

Characteristics of the Subject

\begin{tabular}{|c|c|c|c|}
\hline \multirow{2}{*}{ Variabel } & \multicolumn{2}{|c|}{ Groups } & \multirow[b]{2}{*}{$\mathrm{p}$} \\
\hline & Control & Treatment & \\
\hline \multicolumn{4}{|l|}{ Gender } \\
\hline Male & $14(42 \%)$ & $16(48 \%)$ & \multirow{2}{*}{$0,621^{a}$} \\
\hline Female & $19(58 \%)$ & $17(52 \%)$ & \\
\hline \multicolumn{4}{|l|}{ Age } \\
\hline Adult $(<54$ tahun) & $10(30 \%)$ & $16(48 \%)$ & \multirow[t]{2}{*}{$0,131^{a}$} \\
\hline Elderly ( $\geq 55$ tahun) & $23(70 \%)$ & $17(52 \%)$ & \\
\hline \multicolumn{4}{|l|}{ Highest Education } \\
\hline Didn't go to any school & $5(15 \%)$ & $1(3 \%)$ & \multirow[t]{5}{*}{$0,448^{b}$} \\
\hline Elementary school & $17(52 \%)$ & $14(42 \%)$ & \\
\hline Junior High School & $6(18 \%)$ & $8(25 \%)$ & \\
\hline Senior High School & $4(12 \%)$ & $5(15 \%)$ & \\
\hline College & $1(3 \%)$ & $5(15 \%)$ & \\
\hline \multicolumn{4}{|l|}{ Occupation } \\
\hline $\begin{array}{l}\text { Government } \\
\text { employees/Teacher/Lecturer }\end{array}$ & $0(0 \%)$ & $2(6 \%)$ & \multirow[t]{6}{*}{$0,999 b$} \\
\hline Military/Police & $0(0 \%)$ & $1(3 \%)$ & \\
\hline Farmer/Merchant/Laborer & $12(36 \%)$ & $11(33 \%)$ & \\
\hline Housewife & $13(40 \%)$ & $9(28 \%)$ & \\
\hline Student & $1(3 \%)$ & $2(6 \%)$ & \\
\hline Others & $7(21 \%)$ & $8(25 \%)$ & \\
\hline \multicolumn{4}{|l|}{ Ethnic group } \\
\hline Sunda & $20(61 \%)$ & $20(61 \%)$ & \multirow[t]{2}{*}{$1,000^{\mathrm{a}}$} \\
\hline Not Sunda & $13(39 \%)$ & $13(39 \%)$ & \\
\hline \multicolumn{4}{|l|}{ Income } \\
\hline Very high & $1(3 \%)$ & $2(6 \%)$ & \multirow[t]{4}{*}{$1,000^{b}$} \\
\hline High & $3(9 \%)$ & $3(9 \%)$ & \\
\hline Medium & $5(15 \%)$ & $5(15 \%)$ & \\
\hline Low & $24(73 \%)$ & $23(70 \%)$ & \\
\hline
\end{tabular}

a Pearson Chi-Square Test

b Kolmogorov-Smirnov Test 
Table 2

Subject Frequency Distribution

\begin{tabular}{|c|c|c|c|}
\hline \multirow{2}{*}{ Variable } & \multicolumn{2}{|l|}{ Groups } & \multirow[b]{2}{*}{$p$} \\
\hline & Control & Treatment & \\
\hline \multicolumn{4}{|l|}{ Treatment class } \\
\hline Class I & $19(58 \%)$ & $22(67 \%)$ & \multirow[t]{2}{*}{$0,447^{a}$} \\
\hline Class II & $14(42 \%)$ & $11(33 \%)$ & \\
\hline \multicolumn{4}{|l|}{ Indigestion } \\
\hline Yes & $14(42 \%)$ & $15(45 \%)$ & \multirow[t]{2}{*}{$0,804^{a}$} \\
\hline No & $19(58 \%)$ & $18(55 \%)$ & \\
\hline \multicolumn{4}{|l|}{ Appetite } \\
\hline Good & $3(9 \%)$ & $4(12 \%)$ & \multirow[t]{2}{*}{$1,000^{b}$} \\
\hline Bad & $30(91 \%)$ & $29(88 \%)$ & \\
\hline \multicolumn{4}{|c|}{ Food intake from outside the hospital } \\
\hline Yes & $6(18 \%)$ & $12(36 \%)$ & \multirow[t]{2}{*}{$0,097^{a}$} \\
\hline No & $27(82 \%)$ & $21(64 \%)$ & \\
\hline \multicolumn{4}{|l|}{ Type of the disease } \\
\hline Infection & $7(21 \%)$ & $5(15 \%)$ & \multirow[t]{3}{*}{$0,792^{\mathrm{a}}$} \\
\hline Non-Infection & $22(67 \%)$ & $23(70 \%)$ & \\
\hline Surgery & $4(12 \%)$ & $5(15 \%)$ & \\
\hline
\end{tabular}

Table 3

Differences Patient's Food Satisfaction with Conventional and Room Service System

\begin{tabular}{|c|c|c|c|c|c|c|c|c|}
\hline & \multicolumn{4}{|c|}{ Groups } & \multirow{3}{*}{$p$} & \multirow{3}{*}{$x^{2}$} & \multirow{3}{*}{$\mathrm{RR}$} & \multirow{3}{*}{$\mathrm{Cl}(95 \%)$} \\
\hline & \multicolumn{2}{|c|}{ Control $(n=33)$} & \multicolumn{2}{|c|}{ Treatment $(n=33)$} & & & & \\
\hline & $\mathrm{n}$ & $\%$ & $\mathrm{n}$ & $\%$ & & & & \\
\hline Satisfied & 23 & 70 & 5 & 15 & 0,0001 & 20,10 & 4,6 & $1,99-10,64$ \\
\hline Not satisfied & 10 & 30 & 28 & 85 & & & & \\
\hline
\end{tabular}

Table 4

Patient's Food Acceptance Difference Using Room Service and Conventional System

\begin{tabular}{|c|c|c|c|c|c|c|c|c|}
\hline & \multicolumn{4}{|c|}{ Groups } & \multirow{3}{*}{$p$} & \multirow{3}{*}{$x^{2}$} & \multirow{3}{*}{$\mathrm{RR}$} & \multirow{3}{*}{$\mathrm{Cl}(95 \%)$} \\
\hline & \multicolumn{2}{|c|}{ Control $(n=33)$} & \multicolumn{2}{|c|}{ Treatment $(n=33)$} & & & & \\
\hline & $n$ & $\%$ & $n$ & $\%$ & & & & \\
\hline Good & 28 & 85 & 21 & 64 & 0,0488 & 3,88 & 1,94 & $0,89-4,21$ \\
\hline Bad & 5 & 15 & 12 & 36 & & & & \\
\hline
\end{tabular}

In the same method with variable patient's acceptance, logistic regression on variable food satisfaction was also analyzed. After logistic regression analysis of the result, there are four models that enable to proceed (Table 6). Among the four existing models, models that the best validity and precision is the model 2 . OR obtained from room service to satisfaction after controlling for all confounding variables was $12.11(95 \% \mathrm{Cl} 3.59$ to 37.22$)$. After analyzing confounding variables, age is a confounding factor between room service with patient's satisfaction. Of the two models can be explained that patients given the satisfaction of eating with room service system 12.11 times higher than the satisfaction of patients given conventional system after controlling age variable. 
Table 5

Multivariate Analysis Result between Patient's Acceptance and the Confounding Variables

\begin{tabular}{|c|c|c|c|c|c|}
\hline \multirow[t]{2}{*}{ Model } & \multirow[t]{2}{*}{ OR } & \multicolumn{2}{|c|}{$\begin{array}{c}\text { Confidence } \\
\text { Interval }\end{array}$} & \multirow{2}{*}{$\begin{array}{l}\text { OR difference from } \\
\text { gold standard }(\%)\end{array}$} & \multirow{2}{*}{$\begin{array}{c}\text { precision } \\
\text { (maks-min) }\end{array}$} \\
\hline & & Min & $\operatorname{Max}$ & & \\
\hline $\begin{array}{l}\text { Room service }+ \text { type of disease + education }+ \\
\text { age }+ \text { food from outside the hospital (gold } \\
\text { standard) }\end{array}$ & 2,38 & 0,643 & 8,832 & - & 8,189 \\
\hline $\begin{array}{l}\text { Room service }+ \text { education }+ \text { age }+ \text { food from } \\
\text { outside the hospital (model } 2)\end{array}$ & 2,52 & 0,695 & 9,106 & 5,88 & 8,411 \\
\hline $\begin{array}{l}\text { Room service }+ \text { type of disease }+ \text { age }+ \text { food } \\
\text { from outside the hospital (model } 3 \text { ) }\end{array}$ & 3,05 & 0,874 & 10,640 & 28,15 & 9,766 \\
\hline $\begin{array}{l}\text { Room service }+ \text { type of disease }+ \text { education }+ \\
\text { food from outside the hospital (model } 4)\end{array}$ & 2,37 & 0,649 & 8,658 & 0,42 & 8,009 \\
\hline $\begin{array}{l}\text { Room service }+ \text { type of disease + education }+ \\
\text { age (model } 5)\end{array}$ & 2,39 & 0,674 & 8,456 & 0,42 & 7,782 \\
\hline $\begin{array}{l}\text { Room service }+ \text { type of disease+ education } \\
\text { (model } 6 \text { ) }\end{array}$ & 2,38 & 0,680 & 8,310 & 0 & 7,630 \\
\hline $\begin{array}{l}\text { Room service }+ \text { type of disease }+ \text { age (model } \\
\text { 7) }\end{array}$ & 2,99 & 0,881 & 10,144 & 25,63 & 9,263 \\
\hline $\begin{array}{l}\text { Room service }+ \text { type of disease }+ \text { food from } \\
\text { outside the hospital (model } 8)\end{array}$ & 3.17 & 0,932 & 10,801 & 33,19 & 9,871 \\
\hline Room service + education+ age (model 9) & 2,53 & 0,728 & 8,758 & 6,30 & 8,03 \\
\hline $\begin{array}{l}\text { Room service }+ \text { age }+ \text { food from outside the } \\
\text { hospital (model 10) }\end{array}$ & 3,13 & 0,915 & 10,736 & 31,51 & 9,821 \\
\hline $\begin{array}{l}\text { Room service }+ \text { education }+ \text { food from } \\
\text { outside the hospital (model 11) }\end{array}$ & 2,51 & 0,702 & 8,978 & 5,46 & 8,276 \\
\hline Room service + type of disease (model 12) & 3,11 & 0,935 & 10,333 & 30,67 & 9,398 \\
\hline Room service + education (model 13) & 2,52 & 0,734 & 8,653 & 5,88 & 7,919 \\
\hline Room service + age (model 14) & 3,07 & 0,923 & 10,233 & 28,99 & 9,310 \\
\hline $\begin{array}{l}\text { Room service + food from outside the hospital } \\
\text { (model 15) }\end{array}$ & 3,27 & 0,974 & 10,968 & 37,39 & 9,994 \\
\hline Room service (model 16) & 3,2 & 0,977 & 10,485 & 34,45 & 9,508 \\
\hline
\end{tabular}

Table 6

Multivariat Analysis Result of Variable Patient's Food satisfaction and Confounding Variable

\begin{tabular}{|c|c|c|c|c|c|}
\hline \multirow[t]{2}{*}{ Model } & \multirow[t]{2}{*}{ OR } & \multicolumn{2}{|c|}{$\begin{array}{l}\text { Confidence } \\
\text { Interval }\end{array}$} & \multirow{2}{*}{$\begin{array}{l}\text { OR difference } \\
\text { from gold } \\
\text { standard (\%) }\end{array}$} & \multirow{2}{*}{$\begin{array}{l}\text { precision } \\
\text { (max-min) }\end{array}$} \\
\hline & & Min & Max & & \\
\hline $\begin{array}{l}\text { Room service }+ \text { age }+ \text { food from } \\
\text { outside the hospital (gold standard) }\end{array}$ & 13,45 & 3,700 & 48,860 & - & 45,16 \\
\hline Room service + age (model 2$)^{\star}$ & 12,11 & 3,593 & 40,812 & 9,96 & 37,219 \\
\hline $\begin{array}{l}\text { Room service }+ \text { food from outside the } \\
\text { hospital (model } 3)^{*}\end{array}$ & 14,53 & 4,031 & 52,378 & 8,03 & 48,347 \\
\hline Room service (model 4)* & 12,88 & 3,853 & 43,060 & 4,23 & 39,207 \\
\hline
\end{tabular}




\section{DISCUSSION}

\section{Room service system compared to conventional system affecting the patient's food satisfaction}

This study shows the differences in patient's food satisfaction between the treatment group and control group. Room service increases the satisfaction of the patient's eating significantly. It is evident from the patients who got the system of food preparation conventionally likely to feel dissatisfied by 4.6 times higher compared to patients who receive a serving food system in room service. Although there were 5 patients $(15 \%)$ reported not satisfied with the application of the system of room service, but did not affect the result of the overall study.

Increased satisfaction of eating these patients may be due to the application of room service therefore the patient can decide the right time to eat and get a choice of food they like at that time. In addition, the food condition which is still good and fresh determines the satisfaction of eating as well. The advantages of the room service system are not available on conventional system. Time, the menu is more flexible and the food condition directly impact the patients' satisfaction of eating at hospital. ${ }^{23-}$ 25

This is supported by Norton (2008), who argues that the reason patients like the room service system because patients can decide when they want to eat, patients get what they like and still new (fresh). ${ }^{10}$ Other reasons increased satisfaction in the room service system among others because there is no time limit in eating, food temperature is still appropriate and the variety of menu options. ${ }^{26}$

\section{Room service system compared to conventional system related to patients' acceptance}

Based on the research that has been done, there is a significant difference between the acceptance patients with room service system and conventional system. Patients with conventional system have the possibility of acceptance of the food worse 1.94 times than those with room service system.

Although the number of patients have bad acceptance (64\%) no more than patients who had received a good acceptance $(36 \%)$ after administration of room service system but remained statistically significantly different. A total of 20 of 21 patients (95\%) were known to have acceptance that is not good in the group room service turned out since the beginning of the study did not have a good appetite. Appetite unchanged until the end of the study would affect the acceptance. Nonetheless it has been proven statistically that room service improving acceptability compared with existing conventional systems.

The high acceptance in the group room service is possible because patients prefer to this system. Patients can decide when they want to eat in the room service system and they also get what they like at the time. Additionally, patients receiving the food which is still fresh and more personalized services. ${ }^{10}$ These reasons may trigger increased patient acceptance dining room service system applied in the presentation.

McLymont et al. (2003) explains that 88.24 percent of patients consuming more than half after the implementation of the room service compared to before implementation that is equal to 44.78 percent. ${ }^{26}$ The main factors of patients consume less than 50 percent is because they are sleeping, not in the room, there is a physical examination, or lack of appetite when food was delivered and the application of room service can minimize these constraints.

\section{Factors affecting the relationship room service system with patient's meal satisfaction}

Multivariate analysis showed that age was the only factor in the confounding factor between room service with patient satisfaction. Age can be confounding because of the age group is dominated by elderly subjects. After controlling the confounding factor of age, obtained patients using room service system are 12.11 times more satisfied than those only given conventional system.

As many as 80 percent of the subjects were given a room service and said it was not satisfied with this system is the elderly. Nevertheless the results of the univariate test previously proved that there was no significant difference between the adult age group (54 
years) and elderly ( $\geq 55$ years) with a value of $p$ $=0.131$.

Age is most likely found as a confounding factor due to the different response of each age group. Changes commonly seen in elderly are characterized by changes in the physical and psychological (mental) among others such as anorexia particular, changes in appetite and hunger as well as the lower speed of emptying of the stomach. ${ }^{27-29}$ Payette \& Shatenstein (2005) also explained that changes in eating behavior in the elderly, especially the preference of food caused by factors: biological (the signal changes satiety), palatability (texture of food, changes in stimuli taste, smell and sight), the economic, social and psychological (depression and stress). ${ }^{30}$

Both men and women in the elderly will make adjustments because of those changes in order to be ready to interact with the environment. The result of existing adjustment in the elderly tends to be become too often to choose the food (food pickiness). There is 23 percent of elderly is a picky eater (picker). ${ }^{31}$ In connection with the satisfaction of eating, it could be too many elderly people who tend to choose their food will increase the standard of satisfaction thus likely to feel disappointed with the menu with a few different options.

\section{Factors affecting the application of room service with patients' acceptance}

The result of multivariate analysis is the type of disease and patient education found to be confounding factors between room service and patient's food acceptability. In addition, by controlling the confounding factors of diseases and education found that patients given room service has acceptance 2.38 times higher than the acceptance of patients assigned to conventional system.

The type of disease that affects many subjects here especially the treatment group is non-infectious and non-infectious (70\%). Noninfectious diseases including in internal medicine and metabolic disorders. Patients having those diseases usually given drugs that affect the patient's appetite, either directly or indirectly therefore the acceptance of food is low. ${ }^{32,33}$ This may be related to this research data showing that 95 percent of patients who are known to have bad food acceptance in the group room service turned out to have a meal that does not taste good since the beginning of the study.

In addition to the type of disease, education is one of the confounding variables between the room service and patient's food acceptability. Based on the results of the univariate analysis, it is alleged that the subject of this study is dominated by patients with low level of education and consists of no school and primary school (56\%). In addition, the proportion of subjects who has bad food acceptance was greater in the group who did not go to school at all, elementary and junior high when compared with a group of high school and college education is 86 percent.

Low level of education is usually associated with the rejection of something new included in this room service system. A study conducted in Australia to determine the relationship between education and consumption of food, says that people with higher education tend to eat more varied diet than those with lower education. ${ }^{34}$ Consumption of food was varied indicates that the person is receiving food to be consumed.

Widyaningtyas (2013) asserts that education and type of disease indirectly affect the acceptability through appetite. The results of the study are in accordance with the existing theory education and type of disease may be a confounding factor in the application of room service system and patient's acceptability. ${ }^{35}$

\section{CONCLUSION}

Implementation of the food with room service increases patients' food satisfaction and food acceptance compared with conventional system. Patients given room service 12.11 times more satisfied after controlling for confounding factors of age. In addition, patients given a room service has acceptance 2.38 times higher after controlling for confounding factors of diseases and education.

\section{SUGESSTIONS}

Food serving system using room service is appropriate to be applied in hospitals mainly for the upper class patients and it could be for other grades in some hospital with an appropriate budget. The Hospitals need to improve and develop their food service by room service system. 


\section{ACKNOWLEDGMENTS}

All of the authors contributed to writing this editorial. None of the authors declared a conflict of interest. Financial support for this study was provided entirely by private funding source. We thank the patients who were so agreeable to this study and also Sri Kadaryati, Eva Putri Arfiani, Marina Ayu V. for their assistance.

\section{REFERENCES}

1. Stanga Z, Zurfluh $Y$, Roselli M, Sterchi $A B$, Tanner B, Knecht G. Hospital food: a survey of patients' perceptions. Clin Nutr [Internet]. 2003 Jun [cited 2013 Oct 1];22(3):241-6. Available from: http://linkinghub.elsevier.com/retrieve/pii/S0 261561402002054

2. Barton $A D$, Beigg $C L$, Macdonald $I A$, Allison SP. High food wastage and low nutritional intakes in hospital patients. Clin Nutr. 2000;19(6):445-9.

3. Ordoñez AM, Madalozzo Schieferdecker ME, Cestonaro T, Cardoso Neto J, Ligocki Campos AC. Nutritional status influences the length of stay and clinical outcomes in patients hospitalized in internal medicine wards. Nutr Hosp [Internet]. 2013 [cited 2013 Nov 21];28(4):1313-20. Available from:

http://www.ncbi.nlm.nih.gov/pubmed/238896 58

4. Agarwal $E$, Ferguson $M$, Banks $M$, Batterham M, Bauer J, Capra S, et al. Malnutrition and poor food intake are associated with prolonged hospital stay, frequent readmissions, and greater inhospital mortality: results from the Nutrition Care Day Survey 2010. Clin Nutr [Internet]. 2013 Oct [cited 2014 Nov 2];32(5):737-45. Available from: http://www.ncbi.nlm.nih.gov/pubmed/232606 02

5. Wiboworini B. Pengaruh Penggunaan Menu Pilihan berdasarkan Kesukaan Makan terhadap Tingkat Kepuasan Pasien Paviliun RSUD Dr. Moewardi Surakarta. UGM; 2000.

6. Asfriyentie D. Kesesuaian Biaya Makanan dan Mutu Makanan dengan Daya Terima Pasien RSUD Lubuk Sikaping. 2008.

7. Piddock S. Factors that affect food intake [Internet]. Living Healthy. 2010. Available from:

http://www.livinghealthy360.com/index.php/f actors-that-affect-food-intake-79089/

8. Borges MC, dos Santos F de M, Telles RW, Lanna CCD, Correia IM. Nutritional status and food intake in patients with systemic lupus erythematosus. Nutrition [Internet]. 2012;28(11-12):1098-103. Available from: http://dx.doi.org/10.1016/j.nut.2012.01.015

9. Williams R, Virtue K, Adkins A. Room Service improves patient food intake and satisfaction with hospital food. J Pediatr Oncol Nurs. 1998;15(3):183-9.

10. Norton C. Why Room Service? Is it for your hospital's foodservice operation? MarketLink. 2008;1-3.

11.Schirg GR. Determining the Patient Satisfaction Factors for Hospital Room Service \& The Association of Room Service with the Overall Satisfaction with the Hospital Experience. University of Wisconsin-Stout Menomie; 2007.

12.Vasilion LE. Choice: A Growing Trend in Food Service [Internet]. Dietary Manager. 2004 [cited 2013 Oct 7]. p. 11-4. Available from:

http://www.anfponline.org/Publications/articl es/2004_10_014Choice.pdf

13.Room Service Technologies. What Is Room Service? [Internet]. 2013. Available from: http://roomservicetech.com/id1.html

14.Marcason W. What is the current direction for hospital room service? J Acad Nutr Diet [Internet]. 2012 Mar [cited 2013 May 14];112(3):456. Available from: http://dx.doi.org/10.1016/j.jand.2012.01.005

15.Severson K. For Hospital Menus, Overdue Surgery [Internet]. New York Times. 2006 [cited 2013 Oct 7]. p. 1,3. Available from: http://www.nytimes.com/2006/03/07/health/0 7 patient.html?pagewanted=all\&_r=0

16. Bernstein BC, Winston CP, Atkins M, Caddy J. A hospital food service program to improve customer service and consumer satisfaction scores. J Am Diet Assoc [Internet]. 2011 Sep [cited 2013 May 14];111(9):A62. Available from: http://linkinghub.elsevier.com/retrieve/pii/SO 002822311009369

17. Henroid D, Bhow A., Boyle A., Best J, Minor $C$, Fernandez R, et al. Room service increases nursing satisfaction with hospital food services. J Am Diet Assoc [Internet]. 
2011 Sep [cited 2013 May 14];111(9):A58. Available from: http://linkinghub.elsevier.com/retrieve/pii/S0 002822311009217

18. Kuperberg K, Caruso A, Dello S, Mager D. How will a room service delivery system affect dietary intake, food costs, food waste and patient satisfaction in a paediatric hospital? A pilot study. J Food serv [Internet]. 2008 Oct [cited 2013 May 14];19(5):255-61. Available from: http://doi.wiley.com/10.1111/j.17480159.2008.00103.x

19. Aase S. Hospital food service and patient experience: what's new? J Am Diet Assoc [Internet]. 2011 Aug [cited 2013 May 14];111(8):1118-23. Available from: http://www.ncbi.nlm.nih.gov/pubmed/218025 54

20. Wludyka P. Study Designs and Their Outcomes. In: Macha K, McFonough JP, editors. Epidemiology for Advanced Nursing Practice. 1st ed. Jones \& Bartlett Learning; 2011. p. 81-114.

21. Harris $A D$, McGregor JC, Perencevich EN, Furuno JP, Zhu J, Peterson DE, et al. The Use and Interpretation of QuasiExperimental Studies in Medical Informatics. $\mathrm{J}$ Am Med Informatics Assoc. 2006;13(1):16-23.

22. Lemeshow S, Hosmer Jr. DW, Klar J, Lwanga SK. Besar Sampel dalam Penelitian Kesehatan. Kusnanto H, editor. Yogyakarta: Gadjah Mada University Press; 1997.

23. Messina G, Fenucci R, Vencia F, Niccolini F, Quercioli C, Nante N. Patients' evaluation of hospital food service quality in Italy: what do patients really value? Public Health Nutr [Internet]. 2013 Apr [cited 2013 Nov 12];16(4):730-7. Available from: http://www.ncbi.nlm.nih.gov/pubmed/228747 95

24. Suryawati C, Dharminto, Shaluhiyah Z. Penyusunan indikator kepuasan pasien rawat inap rumah sakit di provinsi Jawa Tengah. J Manaj Pelayanan Kesehat. 2006;9(4):177-84.

25. Rezeki S. Pengaruh Pelayanan Makanan terhadap Kepuasan Pasien Rawat Inap di Rumah Sakit Umum Daerah Kabupaten Aceh Tamiang. USU; 2011.

26. McLymont V, Cox S, Stell F. Improving patient meal satisfaction with room service meal delivery. J Nurs Care Qual. 2003;18(1):27-37.

27. Donini LM, Poggiogalle E, Piredda M, Pinto A, Barbagallo $M$, Cucinotta $D$, et al.

Anorexia and eating patterns in the elderly. PLoS One [Internet]. 2013 Jan [cited 2014 Nov 14];8(5):1-8. Available from: http://www.pubmedcentral.nih.gov/articleren der.fcgi?artid=3642105\&tool=pmcentrez\&re ndertype $=$ abstract

28. Clarkston WK, Pantano MM, Morley JE, Horowitz M, Littlefield JM, Burton FR. Evidence for the anorexia of aging: gastrointestinal transit and hunger in healthy elderly vs. young adults. Am J Physiol Regul Integr Comp Physiol [Internet]. 1997 Jan 1 [cited 2014 Nov 14];272(1):R243-248. Available from: http://ajpregu.physiology.org/content/272/1/ R243

29.Lasari RF. Kesehatan Reproduksi Perempuan saat Lanjut Usia (Aktivitas Seksual pada Masa Perimenopause) [Internet]. 2012 [cited 2014 Sep 4]. Available from:

http://princeskalem.blogspot.com/2012/01/k esehatan-reproduksi-perempuan-saat.html

30. Payette $H$, Shatenstein B. Determinants of healthy aging in community-dwelling elderly people. Can J Public Heal [Internet]. 2005 [cited 2014 Nov 14];96(3):27-31. Available from:

http://journal.cpha.ca/index.php/cjph/article/v iewFile/1502/1691?origin=publication_detail

31. Maitre I, Van Wymelbeke V, Amand M, Vigneau $E$, Issanchou S, Sulmont-Rossé C. Food pickiness in the elderly: Relationship with dependency and malnutrition. Food Qual Prefer [Internet]. 2014 Mar [cited 2014 Jul 17];32:145-51. Available from: http://www.sciencedirect.com/science/article /pii/S0950329313000517

32.McCabe BJ, Frankel EH, Wlofe JJ. Handbook of Food-Drugs Interactions. Florida: CRC Press; 2003. 40-41 p.

33.Ria L. Interaksi Obat dan Makanan [Internet]. 2010 [cited 2014 Oct 9]. Available from: http://lulukria.wordpress.com/2010/02/02/int eraksi-obat-dan-makanan/

34. Worsley A, Blasche R, Ball K, Crawford D. The relationship between education and food consumption in the 1995 Australian National Nutrition Survey. Public Health Nutr 
[Internet]. 2004 Aug [cited 2014 Oct 9];7(5):649-63. Available from: http://www.ncbi.nlm.nih.gov/pubmed/152510 56.
35. Widyaningtyas F. Pengaruh Penyajian ala Bento dengan Persepsi dan Daya Terima Pasien di Bangsal Anak RSUP DR. Sardjito. UGM; 2013. 
